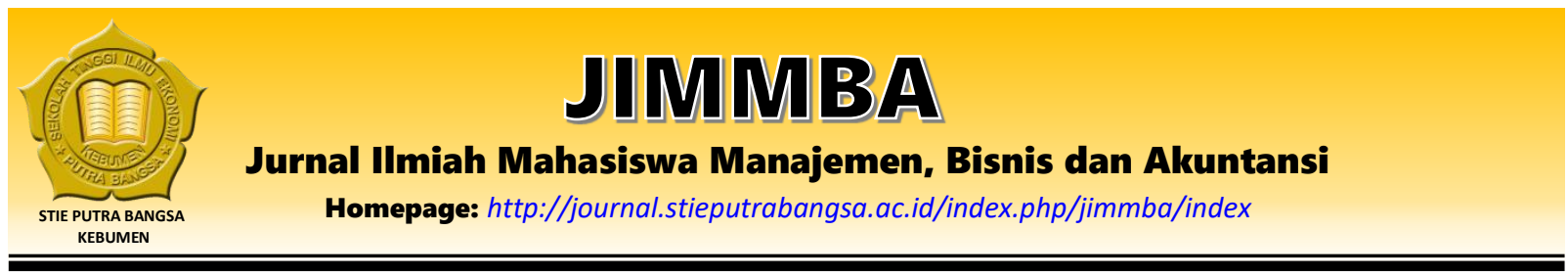

\title{
Pengaruh Audit Manjemen Sumber Daya Manusia Terhadap Kinerja Pengelola Keuangan Desa
}

\author{
Tri Wahyuni' ${ }^{1}$, Susi Astuti ${ }^{2}$ \\ 1,2 Universitas Putra Bangsa \\ triwahyuni180584@gmail.com ${ }^{1}$
}

\section{ARTICLE INFO}

Article History:

Received: August 2nd 2021

Accepted: August $8^{\text {th }} 2021$

Published: October 15th 2021

Kata Kunci:

Audit Manajemen

Sumber Daya Manusia,

Kinerja Pengelola

Keuangan Desa,

Pelaksanaan

Perencanaan,

Penyelenggaraan Fungsi

Orientasi dan

Penempatan,

Penyelenggaraan Fungsi

Pembinaan, Pelatihan

dan Pengembangan

\begin{abstract}
Tujuan penelitian ini adalah menguji pengaruh audit manajemen sumber daya manusia terhadap kinerja pengelola keuangan desa. Analisis data yang digunakan dalam penelitian ini menggunakan metode sampling jenuh. Responden dalam penelitian ini adalah pengelola keuangan desa se-Kecamatan Adimulyo Kabupaten Kebumen. Sampel dalam penelitian ini meliputi Sekretaris Desa selaku Koordinator Pelaksana Teknis Pengelola Keuangan Desa dan Kaur Keuangan selaku Bendahara Desa sebanyak 46 orang. Hasil penelitian menunjukan bahwa audit manajemen sumber daya manusia pada fungsi perencanaan tenaga kerja, fungsi seleksi dan rekrutmen, fungsi orientasi dan penempatan, serta fungsi pembinaan, pelatihan dan pengembangan tidak berpengaruh signifikan terhadap kinerja pengelola keuangan desa di Kecamatan Adimulyo Kabupaten Kebumen.
\end{abstract}

\section{Pendahuluan}

Seiring dengan dikeluarkannya Undang-Undang Nomor 6 Tahun 2014 yang menjadikan desa sebagai subyek pembangunan maka desa memperoleh berbagai macam peluang yang lebih banyak untuk memajukan desa. Undang-Undang desa juga memberi jaminan yang lebih pasti bahwa setiap desa akan menerima dana dari pemerintah melalui anggaran negara dan daerah yang jumlahnya berlipat, jauh diatas jumlah yang selama ini tersedia dalam anggaran desa. Di sisi lain tantangan yang dihadapi pemerintah desa menjadi lebih besar. Sebagai konsekuensi dari dana yang diterima, maka perangkat desa berkewajiban untuk mengelola dana tersebut secara efisien, efektif dan akuntabel.

Kegiatan pengelolaan keuangan desa dapat dilaksanakan dengan baik tentunya harus didukung diantaranya oleh sumber daya manusia yang kompeten dan berkualitas serta sistem dan prosedur keuangan yang memadai. Perangkat desa dikelola dengan manajemen 
sumber daya manusia mulai dari perencanaan SDM, rekrutmen dan seleksi, orientasi dan penempatan, serta pembinaan, pelatihan, dan pengembangan.

Apabila proses manajemen sumber daya manusia dapat berjalan dengan baik diharapkan dapat meningkatkan kinerja aparatur pemerintah desa/perangkat desa dalam penyelenggaraan pemerintahan khususnya pada pengelolaan keuangan desa.

Pengelolaan manajemen yang baik sangat penting untuk mengevaluasi kembali hal-hal yang menyebabkan kinerja perangkat desa kurang maksimal terutama pada pengelolaan keuangan desa. Jika kinerja perangkat desa baik, maka hal tersebut akan berpengaruh positif terhadap pengelolaan keuangan desa.

\section{Kajian Teori dan Telaah Literatur}

\section{Pengertian Kinerja}

Menurut Moeheriono (2012: 95), kinerja atau performance merupakan sebuah penggambaran mengenai tingkat pencapaian pelaksanaan suatu program kegiatan atau kebijakan dalam mewujudkan sasaran, tujuan, visi, dan misi organisasi yang dituangkan dalam suatu perencanaan strategis suatu organisasi.

Mangkunegara (2011: 67), menyatakan: "Kinerja karyawan adalah hasil secara kualitas dan kuantitas yang dicapai oleh seorang karyawan dalam melaksanakan tugasnya sesuai dengan tanggung jawab yang diberikan kepadanya".

Sedarmayanti (2015:133), mengungkapkan faktor-faktor yang mempengaruhi kinerja antara lain:
a) Sikap dan mental (motivasi, disiplin kerja, dan etika kerja)
b) Pendidikan
c) Keterampilan
d) Manajemen kepemimpinan
e) Tingkat penghasilan
f) Gaji dan kesehatan
g) Jaminan sosial
h) Iklim kerja
i) Sarana dan prasarana
j) Teknologi
k) Kesempatan berprestasi

\section{Pengertian Audit}

Arens, dkk (2015: 4) menyatakan: "Audit adalah pengumpulan serta evaluasi bukti tentang informasi untuk menentukan daan melaporkan tingkat kesesuaian antara informasi serta kriteria yang telah ditetapkan."

Mulyadi (2013: 9) menyatakan "Audit adalah suatu proses sistematik untuk memperoleh dan mengevaluasi bukti secara objektif mengenai pernyataan-pernyataan tentang kegiatan dan kejadian ekonomi, dengan tujuan untuk menetapkan tingkat kesesuaian antara 
pernyataan-pernyataan tersebut dengan kriteria yang telah ditetapkan, serta penyampaian hasil-hasilnya kepada pemakai yang berkepentingan.".

\section{Pengertian Audit Manajemen}

Nasrulloh dan Leny (2018 : 11), menyatakan: "Audit manajemen adalah suatu pemeriksaan/tinjauan terhadap setiap bagian dari prosedur operasi, kebijakan-kebijakan dan metode suatu organisasi yang dikelola manajemen, dengan tujuan untuk menilai keefektifan, keekonomisan dan keefesienan pengelolaan operasi organisasi dan pada akhir pemeriksaan akan diberikan rekomondasi atau saran-saran perbaikan yang diperlukan kepada manajemen.".

Bayangkara (2011: 2), menyatakan: "Audit Manajemen (Management Audit) adalah pengevaluasian terhadap efisiensi dan efektivitas operasi perusahaan. Dalam konteks audit manajemen, manajemen meliputi seluruh operasi internal perusahaan yang harus dipertanggungjawabkan kepada berbagai pihak yang memiliki wewenang yang lebih tinggi. Audit manajemen dirancang secara sistematis untuk mengaudit aktivitas, programprogram yang diselenggarakan, atau sebagian dari entitas yang bisa diaudit untuk menilai dan melaporkan apakah sumber daya dan dana telah digunakan secara efisien, serta apakah tujuan dari program dan aktivitas yang telah direncanakan dapat tercapai dan tidak melanggarketentuan aturan dan kebijakan yang telah ditetapkan perusahaan".

\section{Pengertian Manajemen Sumber Daya Manusia}

Setiawan (2012: 19), menyatakan: "Manajemen Sumber Daya Manusia adalah pengelolaan organisasional baik individu maupun kolektif terhadap manusia untuk memberikan kontribusi optimal dalam mencapai sasaran organisasi dengan cara menghindari sebanyak mungkin perlakuan manusia sebagai aset, namun sebaliknya meningkatkan upaya perlakuan manusia sebagai partner."

Sedarmayanti (2016: 37), menyatakan: “Manajemen Sumber Daya Manusia adalah kebijakan dan praktik menentukan aspek manusia atau sumber daya manusia dalam posisi manajemen termasuk merekrut, menyaring, melatih, memberi penghargaan dan penilaian."

\section{Pengertian Audit Sumber Daya Manusia}

Susilo (2010:63) mengungkapkan pengertian audit sumber daya manusia adalah :

"Pemeriksaan dan penilaian secara sistematis, objektif dan terdokumentasi terhadap fungsi-fungsi organisasi yang terpengaruh oleh manajemen SDM (Sumber Daya Manusia) dengan tujuan memastikan dipenuhinya azas kesesuaian, efektivitas dan efisiensi dalam pengelolaan sumber daya manusia untuk mendukung tercapainya sasaran-sasaran fungsional maupun tujuan organisasi secara keseluruhan baik untuk jangka pendek, jangka menengah maupun jangka panjang"

Menurut Bayangkara (2011: 60) audit sumber daya manusia merupakan penilaian dan analisis yang komprehensif terhadap program-program SDM. 


\section{Manajemen Sumber Daya Manusia Perangkat Desa}

Perangkat desa dikelola dengan manajemen sumber daya manusia mulai dari perencanaan SDM, rekrutmen dan seleksi, orientasi dan penempatan, pembinaan, penugasan, pengembangan dan pemberhentian.

\section{Pengertian Pengelolaan Keuangan Desa}

Menurut pasal 71 ayat (1) UU Nomor 6 Tahun 2014 dinyatakan bahwa keuangan desa adalah "hak dan kewajiban desa yang dapat dinilai dengan uang serta segala sesuatu berupa uang dan barang yang berhubungan dengan pelaksanaan hak dan kewajiban desa." Selanjutnya pada ayat (2) dinyatakan bahwa adanya hak dan kewajiban akan menimbulkan pendapatan, belanja, pembiayaan, dan pengelolaan keuangan desa. Pasal 93 ayat (1) UU Nomor 6 Tahun 2014 menyatakan bahwa "pengelolaan keuangan desa meliputi: perencanaan, pelaksanaan, penatausahaan, pelaporan, dan pertanggungjawaban".

Jadi bisa disimpulkan bahwa pengelolaan keuangan desa adalah keseluruhan kegiatan yang meliputi perencanaan, pelaksanaan, penatausahaan, pelaporan dan pertanggungjawaban keuangan Desa.

\section{Model Penelitian}

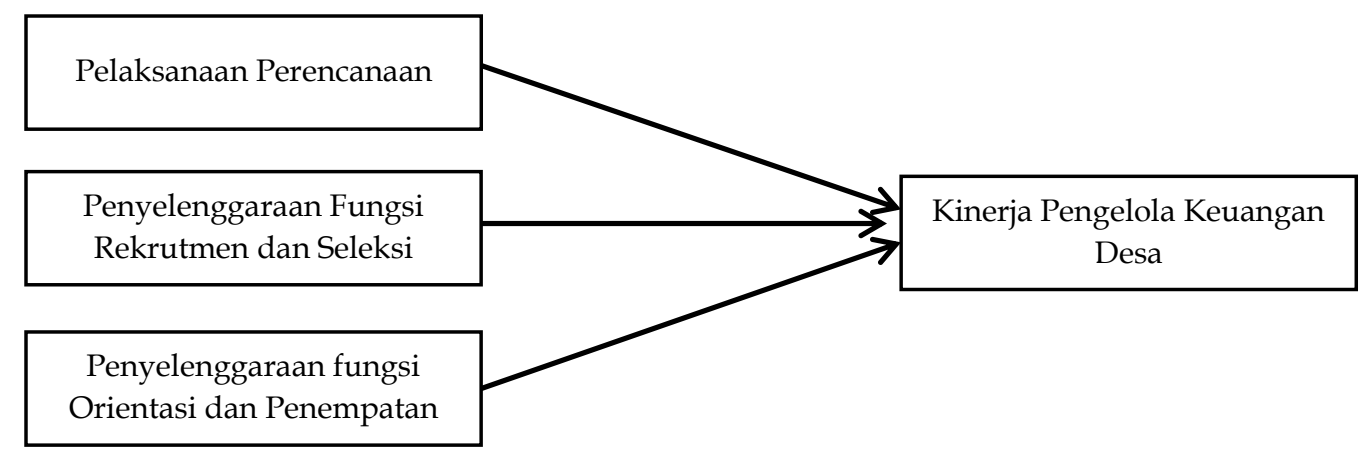

Gambar 1. Model Penelitian

$\mathrm{H}_{1}$ : Terdapat pengaruh audit manajemen sumber daya manusia dalam perencanaan tenaga kerja terhadap kinerja pengelola keuangan desa.

$\mathrm{H}_{2}$ : Terdapat pengaruh audit manajemen sumber daya manusia dalam penyelenggaraan fungsi rekrutmen dan seleksi terhadap kinerja pengelola keuangan desa.

$\mathrm{H}_{3}$ : Terdapat pengaruh audit manajemen sumber daya manusia dalam penyelenggaraan fungsi fungsi orientasi dan penempatan terhadap kinerja pengelola keuangan desa.

$\mathrm{H}_{4}$ : Terdapat pengaruh audit manajemen sumber daya manusia dalam penyelenggaraan fungsi pembinaan, pelatihan dan pengembangan terhadap kinerja pengelola keuangan desa. 


\section{Metode Penelitian}

\section{Objek Penelitian}

Objek penelitian dalam penelitian ini terdiri dari dua variabel yaitu Perencanaan Tenaga Kerja, Penyelenggaraan Fungsi Rekrutmen dan Seleksi, Penyelenggaraan Fungsi Orientasi dan Penempatan, Fungsi Pembinaan, Pelatihan dan Pengembangan sebagai variabel bebas (X), dan Kinerja Pengelola Keuangan Desa sebagai variabel terikat (Y).

\section{Populasi dan Sampel}

Populasi dalam penelitian ini adalah Sekretaris Desa dan Kaur Keuangan selaku Koordinator Pelaksana Teknis Pengelola Keuangan Desa dan Bendahara Desa di Kecamatan Adimulyo Kabupaten Kebumen sejumlah 46 (empat puluh enam) orang. Sampel dalam penelitian ini adalah sekretaris desa dan bendahara desa di Kecamatan Adimulyo Kabupaten Kebumen yang berjumlah 46 orang.

\section{Sumber Data}

Data yang digunakan dalam penelitian ini adalah data primer. Data primer pada penelitian ini adalah hasil angket yang disebar kepada sekretaris desa dan bendahara desa di Kecamatan Adimulyo.

\section{Hasil dan Pembahasan}

\section{Analisis Deskriptif}

Tabel 1. Klasifikasi Responden Berdasarkan Jenis Kelamin

\begin{tabular}{lcc}
\hline \multicolumn{1}{c}{ Jenis Kelamin } & Jumlah Responden & Persentasi \\
\hline Laki-laki & 34 & $76 \%$ \\
Perempuan & 11 & $24 \%$ \\
\hline Jumlah & 45 & $100 \%$ \\
\hline Sumber: Data primer diolah (2021) &
\end{tabular}

Berdasarkan tabel 1 diketahui bahwa mayoritas responden adalah laki-laki sejumlah 34 orang atau $76 \%$ dan responden perempuan sejumlah 11 orang atau $24 \%$ dari total 45 responden.

\begin{tabular}{clc}
\multicolumn{2}{c}{ Tabel } & 2. \\
\hline Usia & Jumifikasi Responden & Berdasarkan Usia \\
\hline $20-30$ & 7 & Prosentase \\
$31-40$ & 16 & $15 \%$ \\
$41-50$ & 17 & $36 \%$ \\
$45-60$ & 5 & $38 \%$ \\
\hline Jumlah & 45 & $11 \%$ \\
\hline Sumber: Data primer diolah (2021) & $100 \%$ \\
\end{tabular}

Berdasarkan tabel 2 diketahui bahwa responden dengan usia 20-30 tahun sebanyak 7 orang atau sebesar $15 \%$. Responden dengan usia 31-40 tahun sebanyak 16 orang atau sebesar 36\%. 
Responden dengan usia 41-50 tahun sebanyak 17 orang atau sebesar $38 \%$. Responden dengan usia 51-60 tahun sebanyak 5 orang atau sebesar $11 \%$.

Tabel 3. Klasifikasi Responden Berdasarkan Lama Bekerja

\begin{tabular}{lcc}
\hline Lama Bekerja & Jumlah Responden & Prosentase \\
\hline 1-5 Tahun & 12 & $27 \%$ \\
5-10 Tahun & 20 & $44 \%$ \\
10 Tahun ke atas & 13 & $29 \%$ \\
Jumlah & 45 & $100 \%$ \\
\hline Sumber: Data primer diolah (2021) & &
\end{tabular}

Berdasarkan tabel 3 diketahui bahwa responden dengan lama bekerja 1-5 tahun sebanyak 12 orang atau sebesar $27 \%$. Responden dengan lama bekerja 5-10 tahun sebanyak 20 orang atau sebesar $44 \%$. Responden dengan lama bekerja di atas 10 tahun sebanyak 13 orang atau sebesar $29 \%$.

\section{Uji Normalitas}

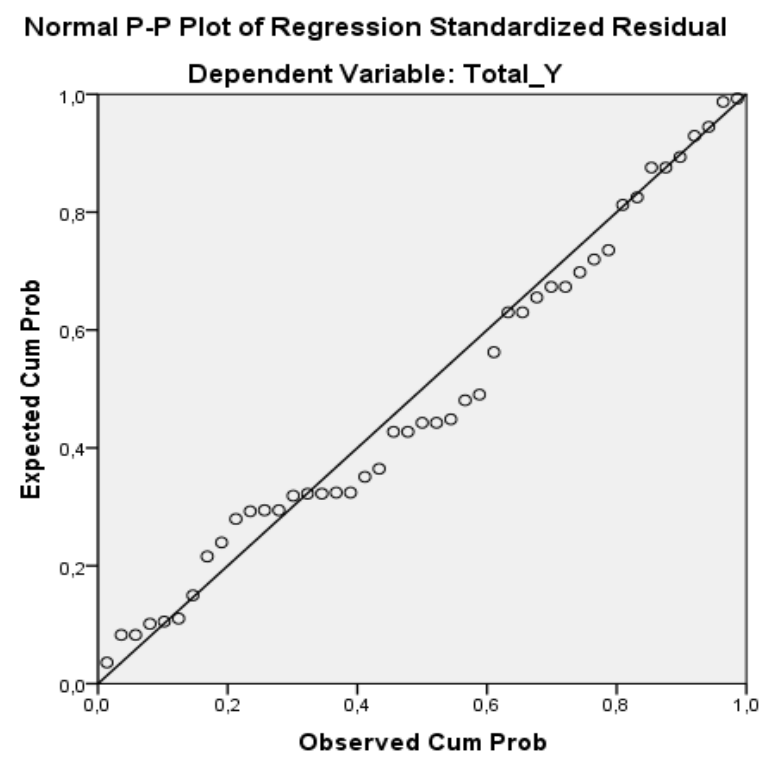

Gambar 2. Grafik Normal P-Plot

Sumber: Data primer diolah (2021)

Berdasarkan gambar 2, terlihat bahwa data menyebar disekitar garis diagonal dan mengikuti arah garis diagonal, maka model memenuhi asumsi normalitas 


\section{Uji Multikolinieritas}

Tabel 4. Output Uji Multikolinieritas

\begin{tabular}{llccccc}
\hline \multirow{2}{*}{ Model } & \multicolumn{2}{c}{$\begin{array}{c}\text { Unstandardized } \\
\text { Coefficients }\end{array}$} & $\begin{array}{c}\text { Standardized } \\
\text { Coefficients }\end{array}$ & \multicolumn{2}{c}{ Collinearity Statistics } \\
\cline { 2 - 6 } & \multicolumn{1}{c}{ B } & Std. Error & Beta & Tolerance & VIF \\
\hline $1 \quad$ (Constant) & 7,520 & 3,620 & & & \\
& X1 &, 193 &, 393 &, 081 &, 590 & 1,696 \\
X2 &, 213 &, 196 &, 174 &, 625 & 1,600 \\
X3 &, 145 &, 139 &, 164 &, 661 & 1,512 \\
X4 &, 229 &, 126 &, 321 &, 519 & 1,928 \\
\hline
\end{tabular}

Sumber: Data primer diolah (2021)

Berdasarkan tabel 4 dapat dijelaskan bahwa pada bagian collinearity statistic menunjukkan angka VIF tidak lebih besar dari 10 dan tolerance lebih dari 0,1. Berdasarkan hasil tersebut dapat diketahui bahwa model regresi ini tidak terdapat moltikolinearitas, sehingga model dapat dipakai.

\section{Uji Heteroskedastisitas}

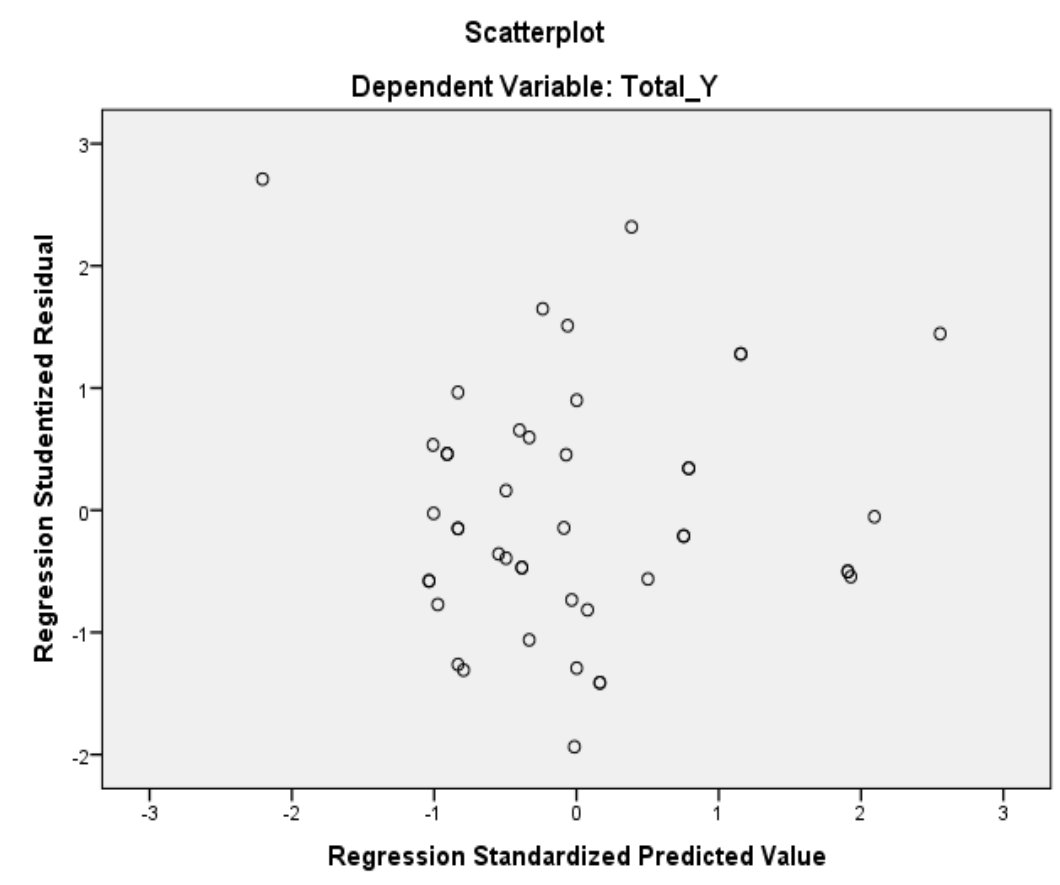

Gambar 3. Grafik Scatterplot

Sumber: Data primer diolah (2021)

Berdasarkan gambar 3 grafik heteroskedastisitas di atas menunjukkan bahwa tidak ada pola tertentu, seperti titik-titik (poin) yang membentuk suatu pola tertentu yag teratur (bergelombang, melebar, kemudian menyempit) dan tidak ada pola yang jelas, maka dapat disimpulkan model regresi dalam penelitian ini tidak terjadi heteroskedastisitas. 


\section{Analisis Regresi Linear Berganda}

Tabel 5. Output Analisis Regresi Linear Berganda

\begin{tabular}{|c|c|c|c|c|c|c|}
\hline \multirow{2}{*}{\multicolumn{2}{|c|}{ Model }} & \multicolumn{2}{|c|}{$\begin{array}{l}\text { Unstandardized } \\
\text { Coefficients }\end{array}$} & \multirow{2}{*}{$\begin{array}{c}\text { Standardized } \\
\text { Coefficients } \\
\text { Beta }\end{array}$} & \multirow[t]{2}{*}{$\mathbf{t}$} & \multirow[t]{2}{*}{ Sig. } \\
\hline & & B & Std. Error & & & \\
\hline & (Constant) & 7,520 & 3,620 & & 2,077 & $\overline{7,044}$ \\
\hline & Pelaksanaan Perencanaan & 193 & 393 & ,081 & 491 & 626 \\
\hline & Fungsi Rekrutmen \& Seleksi & ,213 & 196 & 174 & 1,083 & ,285 \\
\hline & $\begin{array}{l}\text { Fungsi Orientasi \& } \\
\text { Penempatan }\end{array}$ & 145 & 139 & 164 & 1,049 & 300 \\
\hline & $\begin{array}{l}\text { Fungsi Pembinaan, Pelatihan } \\
\text { dan Pengembangan }\end{array}$ & ,229 & 126 & 321 & 1,820 & , 076 \\
\hline
\end{tabular}

Sumber: Data primer diolah (2021)

Berdasarkan hasil pengujian hipotesis dengan uji $\mathrm{t}$ dapat dijelaskan untuk masing-masing variabel bebas sebagai berikut:

\section{Variabel Pelaksanaan Perencanaan Terhadap Kinerja Pengelola Keuangan Desa}

Hasil uji t pada tabel IV-14 diatas, diperoleh nilai thitung sebesar 0,491 dan nilai $t_{\text {tabel }}$ sebesar 2,02108 . Hal ini menunjukan $t_{\text {hitung }}<t_{\text {tabel }}$ dan nilai signifikansi untuk variabel Pelaksanaan Perencanaan (X1) sebesar 0,626> a 0,05 sehingga dapat diambil kesimpulan bahwa variabel pelaksanaan perencanaan tidak memiliki pengaruh terhadap kinerja pengelola keuangan desa. Dengan demikian $\mathrm{H}_{1}$ yang menyatakan bahwa pelaksanaan perencanaan berpengaruh terhadap kinerja pengelola keuangan desa ditolak.

\section{Variabel Fungsi Rekrutmen dan Seleksi Terhadap Kinerja Pengelola Keuangan Desa}

Hasil uji t pada tabel IV-14 di atas, diperoleh nilai $t_{\text {hitung }}$ sebesar 1,083 dan $t_{\text {tabel }}$ sebesar 2,02108 Hal ini menunjukan $t_{\text {hitung }}<t_{\text {tabel }}$ dengan nilai signifikansi untuk variabel fungsi rekrutmen dan seleksi (X2) sebesar 0,285 > a 0,05 sehingga dapat diambil kesimpulan bahwa fungsi rekrutmen dan seleksi tidak memiliki pengaruh terhadap kinerja pengelola keuangan desa. Dengan demikian $\mathrm{H}_{2}$ yang menyatakan bahwa fungsi rekrutmen dan seleksi berpengaruh terhadap kinerja pengelola keuangan desa ditolak.

\section{Variabel Fungsi Orientasi dan Penempatan Terhadap Kinerja Pengelola Keuangan}

Hasil uji $t$ pada tabel IV-14 diatas, diperoleh nilai $t_{\text {hitung }}$ sebesar 1,049 dan nilai $t_{\text {tabel }}$ sebesar $2,02108 \mathrm{Hal}$ ini menunjukan $t_{\text {hitung }}<t_{\text {tabel }}$ dan nilai signifikansi untuk variabel fungsi orientasi dan penempatan $(\mathrm{X} 3)$ sebesar 0,300 > a 0,05, sehingga dapat diambil kesimpulan bahwa variabel fungsi orientasi dan penempatan tidak memiliki pengaruh terhadap kinerja pengelola keuangan desa. Dengan demikian $\mathrm{H}_{3}$ yang menyatakan bahwa fungsi orientasi dan penempatan berpengaruh terhadap kinerja pengelola keuangan desa ditolak.

\section{Variabel Fungsi Pembinaan, Pelatihan dan Pengembangan Terhadap Kinerja Pengelola} Keuangan

Hasil uji t pada tabel IV-14 diatas, diperoleh nilai $t_{\text {hitung }}$ sebesar 1,820 dan $t_{\text {tabel }}$ sebesar 2,02108. Hal ini menunjukan $t_{\text {hitung }}>t_{\text {tabel }}$ dan nilai signifikansi untuk variabel fungsi pembinaan, pelatihan dan pengembangan (X4) sebesar 0,076 < a 0,05, sehingga variabel fungsi pembinaan, pelatihan dan pengembangan tidak memiliki pengaruh terhadap kinerja pengelola keuangan desa. Dengan demikian $\mathrm{H}_{4}$ yang menyatakan bahwa fungsi pembinaan, 
pelatihan dan pengembangan berpengaruh terhadap kinerja pengelola keuangan desa ditolak.

Koefesien Determinasi $\left(\mathbf{R}^{2}\right)$

Tabel 6. Hasil Uji Koefesien Determinasi $\left(\mathbf{R}^{2}\right)$

\begin{tabular}{cccccc}
\hline Model & R & R Square & Adjusted R Square & $\begin{array}{c}\text { Std. Error of the } \\
\text { Estimate }\end{array}$ & Durbin-Watson \\
\hline 1 &, $594^{\mathrm{a}}$ &, 353 &, 289 & 1,853 & 1,423 \\
\hline
\end{tabular}

Sumber: Data primer diolah (2021)

Berdasarkan tabel 6, hasil pengujian menunjukan bahwa nilai Ajusted $\mathrm{R}^{2}$ sebesar 0,353 artinya $35,3 \%$ variabel kinerja pengelola keuanga desa dapat dijelaskan oleh variabel Pelaksanaan Perencanaan, Fungsi Rekrutmen dan Seleksi, Fungsi Orientasi dan Penempatan, Fungsi Pembinaan, Pelatihan dan Pengembangan, sedangkan sisanya sebesar (100\%-35,3\%) atau $64,7 \%$ dapat dijelaskan oleh variabel lain yang tidak ada dalam model penelitian ini.

\section{Pembahasan \\ Pengaruh Audit Manajemen Sumber Daya Manusia pada Pelaksanaan Perencanaan Terhadap Kinerja Pengelola Keuangan Desa}

Berdasarkan uji t maka diperoleh hasil bahwa pelaksanaan perencanaan berpengaruh tidak signifikan terhadap kinerja pengelola keuangan desa. Hal ini disebabkan oleh masih belum optimalnya pelaksanaan perencanaan yang diselenggarakan di desa di Kecamatan Adimulyo.

Visi dan misi masing-masing desa yang selalu disesuaikan dengan masa jabatan Kepala Desa dan aturan-aturan dari pemerintah tentang pengelolaan keuangan desa yang sering berubah membuat pengelola keuangan desa sulit untuk bekerja dengan baik. Selain itu kurangnya pengarahan mengenai tugas dan jadwal kerja yang akan diterima juga menghambat kinerja pengelola keuangan desa. Hasil penelitian ini sejalan dengan penelitian yang dilakukan oleh Sabtohadi dan Ariani (2016 ) yang menyatakan bahwa audit atas perencanaan sumber daya manusia berpengaruh tidak signifikan terhadap kinerja pegawai. Penelitian ini tidak sejalan penelitian Indarti (2020) yang menyatakan audit manajemen sumber daya manusia dalam perencanaan tenaga kerja berpengaruh terhadap kinerja karyawan.

\section{Pengaruh Audit Manajemen Sumber Daya Manusia Fungsi Rekrutmen dan Seleksi Terhadap Kinerja Pengelola Keuangan Desa}

Berdasarkan uji $\mathrm{t}$ maka diperoleh hasil fungsi rekrutmen dan seleksi tidak berpengaruh signifikan terhadap kinerja pengelola keuangan desa. Prosedur pendaftaran perangkat desa sudah berjalan dengan baik, akan tetapi calon perangkat desa tidak diberitahu tentang deskripsi pekerjaannya. Jabatan pengelola keuangan desa juga masih banyak yang tidak sesuai dengan latar belakang pendidikan karena sesuai peraturan bupati syarat untuk pendidikan hanya dicantumkan minimal SLTA.

Indikator-indikator rekrutmen perangkat desa yang masih kurang seperti pelaksanaan indikator calon perangkat desa yang direkrut memiliki kualifikasi pendidikan sesuai dengan jabatan, panitia menentukan persyaratan-persyaratan secara lengkap dalam seleksi bakal calon perangkat desa, dan pelaksanaan rekrutmen perangkat desa dilakukan secara efektif. 
Hasil penelitian ini sejalan dengan penelitian yang dilakukan oleh Sabtohadi dan Ariani (2016) yang menunjukkan bahwa meskipun pengaruh langsung yang diberikan oleh audit atas fungsi rekrutmen dan seleksi adalah positif akan tetapi pengaruh tersebut tidak signifikan secara statistik. Penelitian ini tidak sejalan penelitian Indarti (2020) yang menyatakan audit manajemen sumber daya manusia pada fungsi rekrutmen dan seleksi berpengaruh terhadap kinerja karyawan.

\section{Pengaruh Audit Manajemen Sumber Daya Manusia Fungsi Orientasi dan Penempatan Terhadap Kinerja Pengelola Keuangan Desa}

Fasilitas yang didapatkan perangkat desa memadai, seperti pelayanan kesehatan gratis, gaji sesuai UMR, cuti kerja serta mendapatkan keselamatan saat bekerja. Fasilitas yang diterima oleh perangkat desa tersebut harusnya diseimbangkan dengan kontribusinya, akan tetapi aturan jam kerja yang tidak jelas membuat perangkat desa (pengelola keuangan desa) tidak dapat menggunakan waktu kerja mereka dengan baik. Sesuai Peraturan Bupati Kebumen Nomor 26 Tahun 2018 Tentang Hari Dan Jam Kerja Di Lingkungan Pemerintah Kabupaten Kebumen Bab III pasal 5 mengatur jam kerja efektif diantaranya hari senin - kamis pukul 07.30-16.00 WIB dan hari jumat pukul 07.00-11.00 WIB, akan tetapi aparat pemerintah desa adalah abdi masyarakat dimana pelayanan kepada masyarakat dilaksanakan selama 24 jam dan tidak bisa dibatasi dengan jam kerja sebagaimana Pegawai Negeri Sipil (PNS). Karena sebagai abdi masyarakat dituntut tidak hanya menyelesaikan urusan kantor saja tapi memiliki tanggungjwab untuk membina hubungan masyarakat desa.

Perangkat desa baru tidak ditetapkan sesuai profesi dan kemampuan berdasarkan ijazah sehingga kemampuan dalam mengelola keuangan desa tidak dapat maksimal dan kinerja perangkat desa juga tidak maksimal.

Penelitian ini tidak sejalan dengan penelitian Indarti (2020), yang menyatakan audit manajemen sumber daya manusia pada fungsi orientasi dan penempatan berpengaruh terhadap kinerja karyawan karena dari hasil penelitian bahwa audit manajemen sumber daya manusia pada fungsi orientasi dan penempatan tidak berpengaruh signifikan terhadap kinerja pengelola keuangan desa. Penelitian ini sejalan dengan penelitian yang dilakukan oleh Montolalu et al (2016) yang menyatakan orientasi kerja tidak berpengaruh secara signifikan terhadap kinerja pegawai.

\section{Pengaruh Audit Manajemen Sumber Daya Manusia Fungsi Pembinaan, Pelatihan dan Pengembangan Terhadap Kinerja Pengelola Keuangan Desa}

Kurangnya pelatihan dan pengembangan yang diadakan Pemerintah Kabupaten, Pemerintah Kecamatan maupun Pemerintah Desa membuat pengelola keuangan desa kurang semangat dalam bekerja serta sulit menyelesaikan permasalahan kerjanya. Dapat dikatakan bahwa dengan diterapkannya fungsi pembinaan, pelatihan dan pengembangan yang baik maka semakin meningkat pula kinerja pengelola keuangan desa, akan tetapi karena kurangnya pembinaan dan pelatihan untuk pengelola kuangan desa di Kecamatan Adimulyo sehingga kinerja pengelola keuangan kurang maksimal.

Hasil penelitian ini tidak sejalan dengan penelitian yang dilakukan oleh Pahlevi (2019), Indarti (2020) yang menyatakan bahwa audit manajemen sumber daya manusia pada fungsi pembinaan, pelatihan dan pengembangan berpengaruh terhadap kinerja karyawan. 


\section{Penutup dan Saran}

\section{Simpulan}

Berdasarkan hasil penelitian dan pembahasan yang telah dilakukan, maka dapat diambil kesimpulan sebagai berikut:

Pengujian variable audit manajemen sumber daya manusia dalam aspek perencanaan tenaga kerja menunjukan bahwa perencanaan tenaga kerja tidak berpengaruh signifikan terhadap kinerja pengelola keuangan desa di Kecamatan Adimulyo Kabupaten Kebumen. Hal ini disebabkan karena masih belum optimalnya pelaksanaan perencanaan yang diselenggarakan di desa di Kecamatan Adimulyo. Visi dan misi masing-masing desa yang selalu disesuaikan dengan masa jabatan kepala desa dan aturan-aturan dari pemerintah tentang pengelolaan keuangan desa yang sering berubah membuat pengelola keuangan desa sulit untuk bekerja dengan baik.

Pengujian variable audit manajemen sumber daya manusia dalam aspek rekrutmen dan seleksi menunjukan bahwa rekrutmen dan seleksi tidak berpengaruh signifikan terhadap kinerja pengelola keuangan desa di Kecamatan Adimulyo Kabupaten Kebumen. Dalam proses rekrutmen, prosedur pendaftaran perangkat desa sudah berjalan dengan baik, akan tetapi calon perangkat desa tidak diberitahu tentang deskripsi pekerjaannya. Jabatan pengelola keuangan desa juga masih banyak yang tidak sesuai dengan latar belakang pendidikan.

Pengujian variable audit manajemen sumber daya manusia pada penyelenggaraan fungsi orientasi dan penempatan menunjukan bahwa penyelenggaraan fungsi orientasi dan penempatan tidak berpengaruh signifikan terhadap kinerja pengelola keuangan desa di Kecamatan Adimulyo Kabupaten Kebumen. Salah satu penyebabnya adalah aturan jam kerja yang tidak jelas yang membuat perangkat desa (pengelola keuangan desa) tidak dapat menggunakan waktu kerja mereka dengan baik. Perangkat desa baru tidak ditetapkan sesuai profesi dan kemampuan berdasarkan ijazah sehingga kemampuan dalam mengelola keuangan desa tidak dapat maksimal dan kinerja perangkat desa juga tidak maksimal.

Pengujian variable audit manajemen sumber daya manusia pada penyelenggaraan fungsi pembinaan, pelatihan dan pengembanagan menunjukan bahwa penyelenggaraan fungsi pembinaan, pelatihan dan pengembanagan tidak berpengaruh signifikan terhadap kinerja pengelola keuangan desa di Kecamatan Adimulyo Kabupaten Kebumen. Diterapkannya fungsi pembinaan, pelatihan dan pengembangan yang baik memang dapat meningkatkan kinerja pengelola keuangan desa, akan tetapi karena kurangnya pembinaan dan pelatihan untuk pengelola kuangan desa di Kecamatan Adimulyo sehingga kinerja pengelola keuangan kurang maksimal.

\section{Saran}

Berdasarkan hasil penelitian serta hal-hal yang terkait dengan keterbatasan penelitian ini, maka dapat diberikan saran-saran sebagai berikut: 1.) Variabel yang digunakan dalam penelitian ini hanya meliputi Audit Manajemen Sumber Daya Manusia dalam menilai kinerja pengelola keuangan desa. Peneliti selanjutnya untuk dapat mengembangkan 
penelitian ini dengan mempertimbangkan variable-variabel lain, diluar variabel yang ada dalam penelitian ini; 2.) Peneliti selanjutnya di harapkan dapat menguji pada sempel atau di desa kecamatan lain di Kabupaten Kebumen.

\section{Referensi}

Annisa, N. P. (2016). Pengaruh Audit Manajemen Sumber Daya Manusia Terhadap Kinerja Karyawan di Rumah Sakit Umum Purbowangi. Skripsi. Fakultas Ekonomi Universitas Negeri. Yogyakarta

Arens, A. A., Elder, R. J., \& Beasley, M. S. (2015). Auditing dan Jasa Assurance. (Alih bahasa: Herman Wibowo). Jakarta: Salemba Empat.

Astuti, S. (2018). Peran Audit Manajemen Sumber Daya Manusia Terhadap Kinerja Karyawan Instalasi Rawat Inap Di Rumah Sakit (Studi Kasus pada Rumah Sakit Umum Daerah Dr. Soedirman Kebumen). Fokus Bisnis: Media Pengkajian Manajemen dan Akuntansi, 17(1), 1-23.

Bayangkara, I. B. K. (2011). Audit Manajemen: Prosedur dan Implementasi. Salemba Empat. Jakarta.

Gelinas, U. J., Sutton, S. G., \& Hunton, J. (2016). Accounting Information System. 10. Edition. South_Western.USA.

Ghozali, I. (2013). Aplikasi Analisis Multivariate dengan Program IBM SPSS 21 Update PLS Regresi. Semarang: Badan Penerbit Universitas Diponegoro.

Ghozali, I. (2016). Aplikasi Analisis Multivariatif dengan Program IBM SPSS 19. Cetakan VIII Badan Penerbit Universitas Diponegoro. Semarang.

Indarti, D. (2020). Pengaruh Audit Manajemen Sumber Daya Manusia terhadap Kinerja Karyawan di Puskesmas Pejagoan Kabupaten Kebumen. Laporan Tugas Akhir. D3 Akuntansi Universitas Putra Bangsa. Kebumen.

Mangkunegara, P. A. A. A. (2011). Perencanaan dan Pengembangan Sumber Daya Manusia. Bandung: Refika Aditama

Moeheriono, M. (2012). Badan Pertanahan Nasional. Manajemen Kinerja. Jakarta: Raja Grafindi Persada.

Montolalu, R., Kawet, L., \& Nelwan, O. (2016). Pengaruh kepribadian, orientasi kerja dan penempatan pegawai terhadap kinerja pegawai pada dinas kebudayaan dan pariwsata provinsi sulawesi utara. Jurnal EMBA: Jurnal Riset Ekonomi, Manajemen, Bisnis dan Akuntansi, 4(1).

Mulyadi, M. (2013). Auditing. Buku I. Edisi 6. Salemba Empat. Jakarta.

Nasrulloh, N., \& Nofianti, L. (2018). Pemeriksaan Akuntan Publik. Pekanbaru.

Notoatmodjo, S. (2015). Metode Penelitian Kesehatan. Jakarta: Rineka Cipta. 
Pahlevi, D. H. (2019). Pengaruh Audit Manajemen Sumber Daya Manusia Terhadap Kinerja Karyawan Instalasi Gawat Darurat Di RSUD DR. Soedirman Kabupaten Kebumen. Laporan Tugas Akhir. D3 Akuntansi Universitas Putra Bangsa. Kebumen.

Peraturan Bupati Kebumen Nomor 26 Tahun 2018 Tentang Hari Dan Jam Kerja Di Lingkungan Pemerintah Kabupaten Kebumen

Peraturan Menteri Dalam Negeri Nomor 84 Tahun 2015 tentang Pedoman Susunan Organisasi dan Tata Kerja Pemerintah Desa

Rivai, V., \& Sagala, E. D. (2013). Manajemen Sumber Daya Manusia Untuk Perusahaan. Jakarta: Rajawali Pers.

Samsudin, S. (2009). Manajemen Sumber Daya Manusia. CV Pustaka Setia. Bandung.

Sedarmayanti., S. (2016). Manajemen Sumber Daya Manusia (Reformasi Birokrasi dan Manajemen PNS). Bandung: PT. Rafika Aditama.

Setiawan, T. (2012). Manajemen Sumber Daya Manusia. Jakarta: Platinum.

Siagian, P. S. (2001). Manajemen Sumber Daya Manusia. Jakarta: Bumi Aksara.

Sugiyono, S. (2010). Metode Penelitian Bisnis. Bandung: Alfabeta.

Sugiyono, S. (2013). Metode Penelitian Kuantitatif, Kualitatif dan RED. Bandung: Alfabeta.

Sujarweni, V.W. (2014). SPSS untuk Penelitian. Yogyakarta: Pustaka Baru Press.

Sukrisno. A. (2012). Bunga Rampai Auditing. Jakarta: Salemba Empat.

Susilo, W. (2010). Audit Sumber Daya Manusia, Jakarta: PT. Vorqistatama.

Sutrisno, E. (2011). Menajemen Sumber Daya Manusia. Jakarta: Kencana.

Umar, H. (2013). Metode Penelitian untuk Skripsi dan Tesis. Jakarta: Rajawali.

Undang-Undang Nomor 6 Tahun 2014 tentang Desa.

Undang-Undang Nomor 13 Tahun 2003 tentang Ketenagakerjaan. 